\title{
Prophetical Law Paradigm: A Synthesis Of Thoughts Of Legal Philosophy Development
}

\author{
Catur Yunianto \\ IKIP PGRI Jember \\ caturyunianto@ikipjember.ac.id \\ DOI: https://doi.org/10.23917/jtl.v1i2.9154
}

\section{Submission}

Track:

Received:

02 November 2019

Final Revision:

05 Februari 2020

Available online:

14 Februari 2020

Corresponding

Author:

Catur Yunianto

caturyunianto@ikipjember.ac.id

\begin{abstract}
Purpose: This article aims to explain the philosophy dialectics of positivistic law and post positivistic law and elaborate on the dialectics of synthesis of thoughts of prophetic legal.
\end{abstract}

Methodology: This research used a philosophical approach. The data were taken from secondary data using primary and secondary legal materials. The data were presented in an analytical descriptive manner, then analyzed in a normative juridical manner.

Finding: The development of legal philosophy as an art of thought between empiricism, reality, rationality, and irrationality. Integration must be in presence to find the legal synthesis which is perceived capable of providing answers to the missing synthesis concerning the law. The basis of integration is conducted by retrieving the history and the thought schools development of natural philosophy, positivistic, non-systematic law and prophetic law. The synthesis of the thought schools of philosophical law is not only a reality built from the law itself but also the existence of extracurricular nullifications that can be synergized into near-perfect law.

Importance: The benefit of this research is to present the phenomena of various legal paradigms that develop simultaneously as a synthesis of legal development and as an answer to various problems of legal philosophy. The positivistic, non-systematic synthesis and the prophetic paradigm are the paths to near-perfect truth.

Originality/Novelty: The prophetic paradigm developed within the framework of micro and macro realities are considered capable of providing answers to the reality of various criticisms that have existed so far. This prophetic paradigm has bonded micro, macro and transcendent realities which are divided into three categories; Theology, Humanity and Natural Sciences which are based on God's verses on the Qur'an and Sunnah.

Keyword: Philosophy of Law, Synthesis, Prophetic 


\section{INTRODUCTION}

The issue of law enforcement is a very important matter to create order, peace, and security in the life of a society. The law basically functions to protect human interests, thus, the law must be upheld to create an orderly and peaceful society. Regarding the law enforcement efforts in Indonesia, as a country practicing Pancasila, it is used as a life guideline of the nation and state amid complex legal developments. Existing law is an accumulation of reconstructions from a long history of law. Whether the content, reality and philosophy, the history of law provide views and references of change and construction with reality.

The reality dimension of these legal thoughts began in the fourth and sixth centuries, starting from the east (China and India) to the region around the Mediterranean, with a variety of deep questions and problems about concepts, ideas, anatomy of the cosmos, theology, abstracts, anthropocentric rules that created a variety of unique dialectical phenomena and transformation of views of thought that give thought to the birth of new streams of knowledge. So as in the case of legal thoughts that are grounded in the natural values of natural law which are manifested in its anthropocentric circles of reason, which Thomas Aquinas explains in terms of:

1. Lex aeterna: the law of God: this only can be seen and explored by God himself, only a few laws that are introduced to humans through revelation

2. Lex Divina/Divine law

3. Lex Naturalis/natural law: part of the law that can be discovered by humans through their minds

4. Positive law: the implementation of natural law by humans, related to special conditions required by the conditions on earth. ${ }^{1}$

To Grotius and Kant, this school believes that to achieve the cosmos's desires, it must be maintained in accordance with the function of the predetermined natural circle, so based on the substance of the teachings, it will introduce human submission to natural and religious phenomena in their absolute frame and not allow any space to appreciate reasoning in 
interactions with cosmo. This law also proves that there are fundamental demands in human real-life as a form of intelligent beings. Humans must not follow their irrational instincts but consider reason and moral sense above all 2 .

In turn, humans are only enslaved by desires as in line with criticism stated by David Hume circa $18^{\text {th }}$ century, the reason is and ought to be the slave of passions ${ }^{3}$. This criticism by David Hume has indirectly been breakthrough to the foundations of natural law so the development of natural law has been replaced since 1600s-1800s with positivistic school, which is to enlighten thoughts of natural law that are dominated by the Divine teachings thus it can be enlightened to create a social life together ${ }^{4}$ apart from politics, economics, and morals in an objective frame as a rule of positive norms, which are no longer conceptualized as abstract morals but ius which has been positively changed as lege or lex, to achieve true legal certainty.

In the framework of Jhon Austin's opinion, placing the highest law is in the cope of State or other words under the law of the State, or the phase of its development into law is an order from the highest political holder to the lower political holder, this is evident that the law must be rational in the State's norm frame.

Hans Kelsen is one of the figures who have contributed to the development and thoughts of legal positivism. Hans Kelsen's thought that is famous for stufenbau describing the concept of law that must be derived from non-juridical analysis, such as sociology, politics and history, and the exclusion of non-legal variables ${ }^{5}$. The purification of law from non-legal elements, (epistemologically) is the final and absolute basis for Kelsen. Many refer to Hans Kelsen as the founder of the theory and the science ${ }^{6}$ of law into the independent discipline (autonomous discipline). The law is nothing but a rule of order that requires people to obey as they should.

In the perspective of positivism, no law other than the command of the authorities/laws that must be followed to create an order based on State law. This positivist stream receives a lot of criticism because positivism is unable to explain the phenomena of the development of the existing law, the biological analysis that is transformed into the social analysis is 
considered as the root of the decline of spiritual values or even human values. This occurs because humans are reduced to the physical-biological definition, Positivism, in fact, focuses on something that can be seen as the object of the study, in which it is dependent on the five senses, positioning reason in every aspect to facilitate the search for truth is not inevitably blessings, but reason in a positivism view unwittingly has brought people to the stream and hedonism and excessive desires that escape from religious nature so the legal meaning is free from the benefits, humans are only limited to tools that run mechanically without realizing the creator, there is a hollow that disappears from reality as a human so that positivistic polemic has become a dilemma when confronted with Macro reality, thus, dialectics are needed to overcome micro and macro realities.

\section{RESEARCH PROBLEM}

1. What are the dialectic philosophy of positivistic law and dialectic philosophy of post positivistic law?

2. What is the dialectic synthesis of prophetic thought?

\section{RESEARCH METHODS}

This research used a philosophical approach. The data were taken from secondary data using primary and secondary legal materials. The data were presented in an analytical descriptive manner and then analyzed in a normative juridical manner.

\section{DISCUSSION}

\section{A. Dialectic of Positivistic Law}

Reason is God's gift to think. By thinking, it will obtain a phenomenon about what is right and wrong, rational-irrational or matters that are basically determined to collide with each other. The results of these collisions will create the objectivity of true science according to the meaning of each individual. So as the case with legal thoughts, which in the 
development of law is still developing to find new recipes that are considered in accordance with the state of a society and nation. The schools of legal thoughts color the formation of the law itself, from the schools of natural law, positivism, and prophetic.

The school of natural law is considered the oldest school of the reality of human thought regarding the law. The history of "natural law" is the history of mankind in its quest to find "absolute justice" and the history of human failure in his efforts ${ }^{7}$.

Philosophy of natural law philosophy has two versions of Greek and Roman thoughts. Greek thought was pioneered by the philosophers Plato, Aristotle and the Stoic, while the Roman thought was pioneered by the ideas of Cicero, Gaius, although their thoughts were also inspired by many Greek thinkers. The ideas of Greek and Roman natural law are basically similar, that is, to emphasize that laws are God's rules and humane conditions but cultural differences cause the development of natural law in the two nations to differ, in which the Greeks emphasize theoretical and philosophical law (ontology and epistemology) whereas the Romans are more likely at the practical aspects (epistemology and axiology) which originated in the cosmos, the good rule is the cosmos itself. The Greek and Roman thoughts had brought natural law to the nature of its believers and admirers so they perceive natural law into three thoughts; rationalism, irrationalism, empiricism.

The rationalism is fronted by Hugo De Grots, Imanuel Kant. Rationalism in their thinking about natural law is to prioritize rational thinking, and empiricism experience, natural law was born from the essence of humanity itself even though human essence was created by God, morals are the main element because with the absence of morality the law will lose its supremacy. Irrationalism was found by Thomas Aquinas who views universal law as essentially the extension of God's hand on earth that cannot be captured by humans through the senses, natural law as the participation of rational beings in eternal law ${ }^{8}$, whereas in empiricism thought, natural law is fronted by Jhon Locke see natural law born from the results of human manifestations that are actualized in their universal and eternal behavior.

The essence of natural law in the view of Curzon's ${ }^{9}$ thought is as follows: 
1. The unerring law is right; non an ordinance mad by this or that mortal, a corruptible and perishable law, but one imperishable and impressed by immortal Nature on the immortal mind. Philo of Alexandria (first century)

2. Natural law which is observed equally in all nations, being established by divine providence, remain forever settled and immutable; but that law which each state has established for itself is often changed: Justinian (sixth century)

3. The state of nature has a law of nature to govern it... in transgressing the law of nature the offender declares himself to live by another rule than that of reason and common equity: hobbes (seventeenth century)

4. Natural law is a divine law, written in the hearts of all men, obliging them to do those things which are necessary consonant to the rational nature of mankind and to refrain from those things which are repugnant to it: Thomasius (eighteenth century)

5. Natural law, resting on the postulate of the rectitude of nature, is necessarily absolute. As an end in itself, it is to be vindicate for its own sake; Lorimer (nineteenth century)

6. Man is made for an end, and therefore there is a law which comes before him, a law which he must apply to himself in order to attain the and which is, demonstrably, none other than God. This law is a natural law: Miltner (twentieth century)

7. Because an act in harmony with the objective order is a morally good act, and because an act at discord with the same order is a morally bad act, it is natural law's information function to make clear to man the difference between good and evil or right an wrong: Hill (twentieth century)

8. There is, by the very virtue of human nature, an order or disposition which human reason can discover and according to which the human will must act in order to attune itself to the necessary ends of the human being. The unwritten law, or natural law, is nothing more than that: Maritain (twentieth century).

Broadly speaking, natural law is universally applicable laws, in the cosmology nature itself. There is an acknowledgment of an ideal universal legal system created by God and nature itself, given the difference in the same frame, which is universal nature. The most meritorious contribution of natural law thought is equality and fair treatment of human, it is not a law if it fails to be fair, limitless to time and place, and this is essentially universal. The natural law problem is still "current" and has not been "solved". Through the changing state of society and the political situation, the understanding of natural law has changed ${ }^{10}$.

In its development, natural law has been criticized by those who find natural law as incompatible with the current of society. For instance, the explanation of the concept of fairness in natural law, or existing law must be sourced from nature, while other elements do 
not originate from nature that influences law, which is unacceptable in the frame of reasoning of legal reality. The contradiction between nature and law which is concluded in the sense of natural law thus earns a solution that is only seen from one angle: the definition of law is sacrificed to the definition of nature ${ }^{11}$. Eventually, the natural law is considered to run outside the legal realities. To explain this phenomenon, the flow of legal positivism emerges.

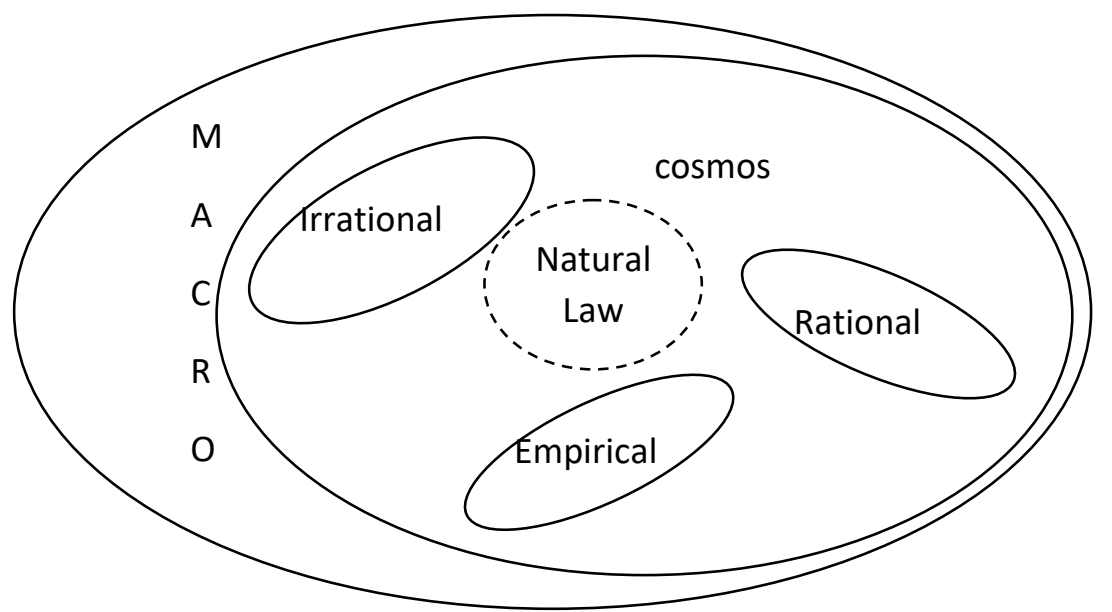

Figure 1. The flow of legal positivism

Positivism was found in France, as a result of the upheaval of middle-class society with the aristocrats, which eventually created the Renaissance between circa $14^{\text {th }}$ century and $17^{\text {th }}$ century. The Renaissance created a new world order, a traditional transition (metaphysical) into the industrial era (mechanical and factual), the shifting irrational thought to rational milieu entitled this century as the turning point of enlightenment, as the starting point of civilization in Europe that developed throughout the world. Undoubtedly, modern science has a limited form of objectivity in learning natural knowledge and begins to forget the nature of the Theology they originally glorified which eventually triggered the original of positivistic school with its pioneers, Rene Descartes, Auguste Comte, and Immanuel Kant.

Positivism with the basis of epistemology confirms about facts that objects used as research/study must be empirically observed through the five senses, factually confirms there is no reality beyond the seen world, positivistic school rejects natural laws that are too 
idealistic, which places legal ontology at an absurd level ${ }^{12}$ as a sharp criticism of the natural law stream.

Legal positivism, in the view of Rene Descartes, views law rationally (factual) which explains that the law is sourced from humans which can be generally methodologized, ratioed, and fixed. Being eager to find an undoubted truth. The truth, he stated, is we cannot doubt of our existence while we doubt. The statement is famous for its motto cogito ergo sum ${ }^{13}$. The certainty that "someone is thinking" provided Descartes the foundation he needs to build knowledge. He had established it with the doubtfulness method and using what he called "the light of reasoning". He continued to offer two arguments for the existence of God. The first argument begins with the awareness of his existence as the yield of his doubts, imperfect but can create the idea of God a perfect entity. ${ }^{14}$

Auguste Comte's positivism departs from theology, metaphysics, and positivism. The theological stage that places the whole world into other than nature or what lies beyond. This stage of thinking, human directs the soul to the inner nature of all matters, to the first call, and the ultimate goal of all things. According to him, the objects in this era were expressions of supernaturalism, from a belief of the existence of magical powers in certain objects, this is the most primitive theological stage. Also, the belief in many Gods, at that time people retrieved certain things all together as the descend of a supernatural power, that motivated and then became the monotheism as the highest stage in which at that time humans gathered their Gods into one supreme figure. The metaphysical stage is a modification of the theological stage, at this stage, humans begin to overhaul ideas, construct and find nature and something and start to leave the irrationality and dogma of religion. The metaphysical stage is a period whereof change from the theological period, wherein this period one only believes in one doctrine and will not criticize. When a man reaches the metaphysical stage, he begins to wonder and starts to look for concrete evidence to the view of doctrine.

Kant's thought was influenced by Hume, the sole character of right is noncontradictory law. If a certain proposition is not properly rejected without contradiction, it must be true. Otherwise, with the same logic, the opinion does not express anything beyond what is assumed by the concepts it contains. Besides, Immanuel Kant followed the Grotius 
line of thinking that emphasizes the role of the human ratio in the front lines, so that the human ratio is completely freed from God. Therefore, the human ratio is the solitary source of law. The essence of the law for Kant is that the law is the whole condition in which one's own will can be combined with the will of others under the general freedom law which includes all. Kant required that all members of society continue to abide by the positive law of the state even though there are contradict elements to the basics of humanity. Positivism analyzes intellect and life according to the basics of "causality" followed by a revolution in the way of thinking ${ }^{15}$. This new way of thinking is "instinct" (instinct), no longer "reason". ${ }^{16}$

Laws are command from the authorities. The nature of the Law, according to Austin, lies in the "command" element. The law is seen as a fixed, logical, and closed system. It enforces the law by threatening and directing the behavior of others towards their desire, the law is separated from justice and is not backed by good or bad understanding but based on the power of a superior. Austin's positivism does not recognize the relationship between law and "what is good" or "what is bad", the law of God only has a function as a "container". 18

Kelsen was included as a Neo-kantianism because he used Kant's thought about the separation of form and content. On Kelsen's view, law deals with form ant not material. So, justice as the content of the law is outside the law. A law can be unfair but it is still a law because it is issued by the authorities. Kelsen wanted to cleanse law from non-legal, historical, sociological and political factors, Kelsen viewed law as is, which is rule created and legalized by the state, ${ }^{19}$ while Grundnorm has a function as the basic reason that the law is obeyed and is responsible for the implementation of law, thus, the grundnorm between the existing law structure in A does not have to be identical with the law order in $\mathrm{B}^{20}$

Positivism developed into two main types of positivism, analytical positivism, and pragmatic positivism. Analytical positivism considers the basis of legal norms as determined by lawmakers as certain stance and focuses on analyzing understanding and legal relations on the basis of an absolute difference between is and ought ${ }^{21}$, while pragmatic positivism considers social factors as the shape of the law. 


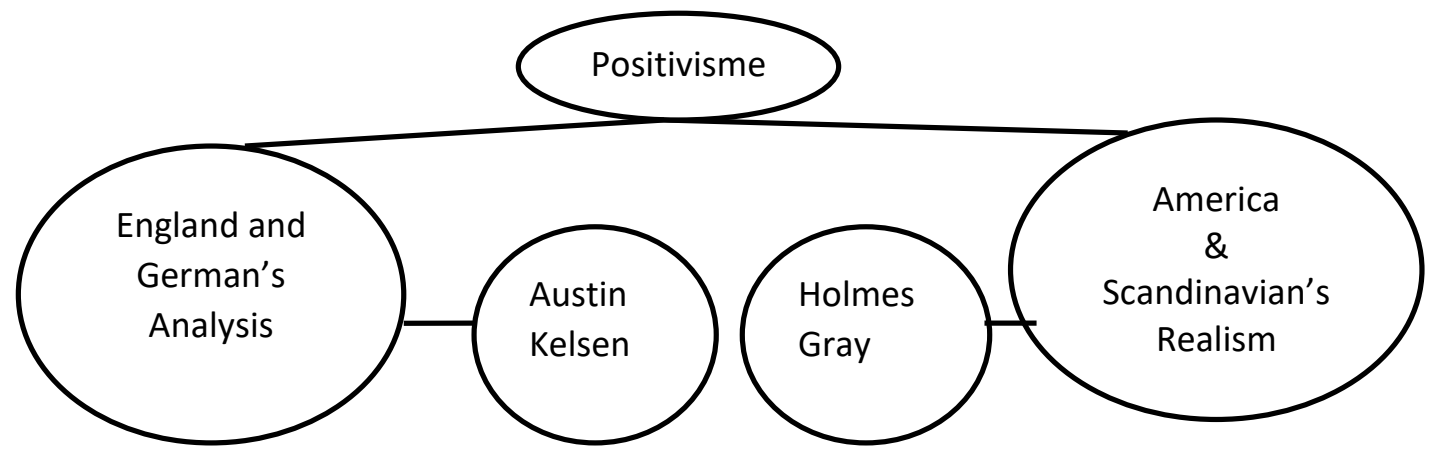

Figure 2. Definition of positivism

\begin{tabular}{|c|c|c|}
\hline \multirow{4}{*}{ Positivism } & Austin's Analysis & America's Realism \\
\hline & $\begin{array}{l}\text { 1. Law is considered as } \\
\text { fixed, logic and closed } \\
\text { system } \\
\text { 2. Law is the sovereign } \\
\text { command }\end{array}$ & $\begin{array}{l}\text { 1. No realist school } \\
\text { 2. Realism implies the } \\
\text { conception of ubiquitous } \\
\text { law and tool to achieve } \\
\text { the social goals } \\
\text { 3. Realism does not believe } \\
\text { in terms and definition of } \\
\text { traditional law }\end{array}$ \\
\hline & Kelsen's Analysis & Scandinavian's Realism : \\
\hline & $\begin{array}{l}\text { 1. The separation of } \\
\text { form and content } \\
\text { 2. Law naturally and } \\
\text { scientifically is not } \\
\text { combined with } \\
\text { instinct, will and } \\
\text { desire }\end{array}$ & $\begin{array}{l}\text { Continental pattern in critical } \\
\text { and abstract explanation. } .^{23}\end{array}$ \\
\hline
\end{tabular}

Table 1. Differences in Positivism 
It is obvious that the positivism thinking path is realism which can be proven rationally. Thus, the provisions of the law must be separated from the elements outside the law, such as politics, economics, and sociology.

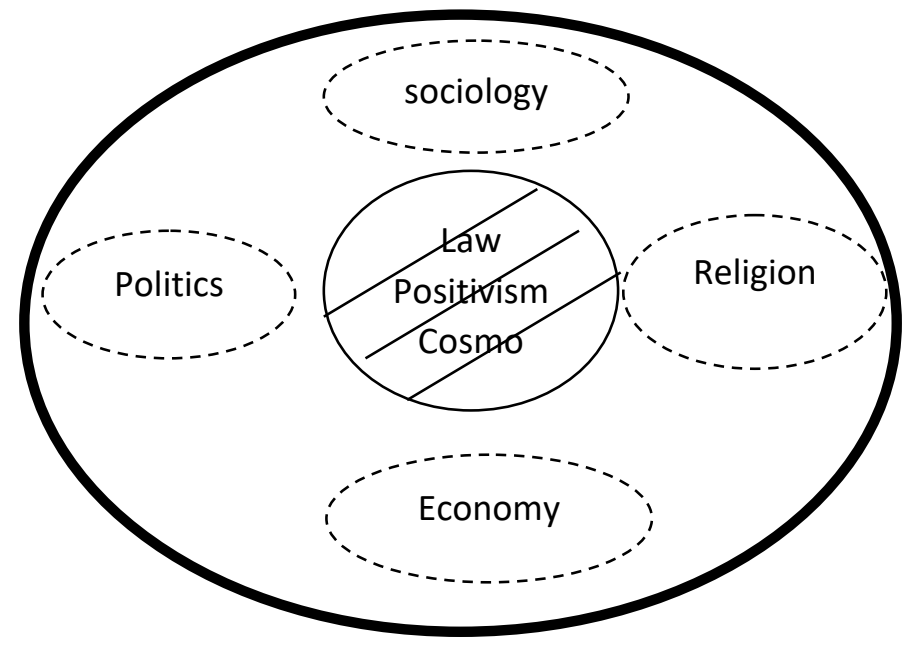

Figure 3. The flow of thinking positivism

When positivistic law is separated from the elements outside its cosmos, the law has shown its gap. These weaknesses among others are; a. assumptions about legal certainty, b. assumptions regarding the objective reality, the subject must be separated from the object, the text out of context, c. assumption of reductionism, d. deterministic assumptions, e. value-free assumption $^{24}$. The influence of the positivistic school creates a civilization which releases the theological phenomenon as an irrational phenomenon, which is not factual.

Considering everything must be objective and known (nothing suddenly exists). The divine dimension is detached from the positivism dimension. This dimension is interpreted by the existence of mature scientific interpretations and can be captured with the five senses (broadly understood). Divine positivism can be seen in the broader range of religion, ethics and morality, which are no longer understood in merely one aspect, which is the aspect related to theological and desire solely, but more than the question of values that can be dialogued with the problem of development scientific, social, cultural, economic and legal development. $^{25}$ 


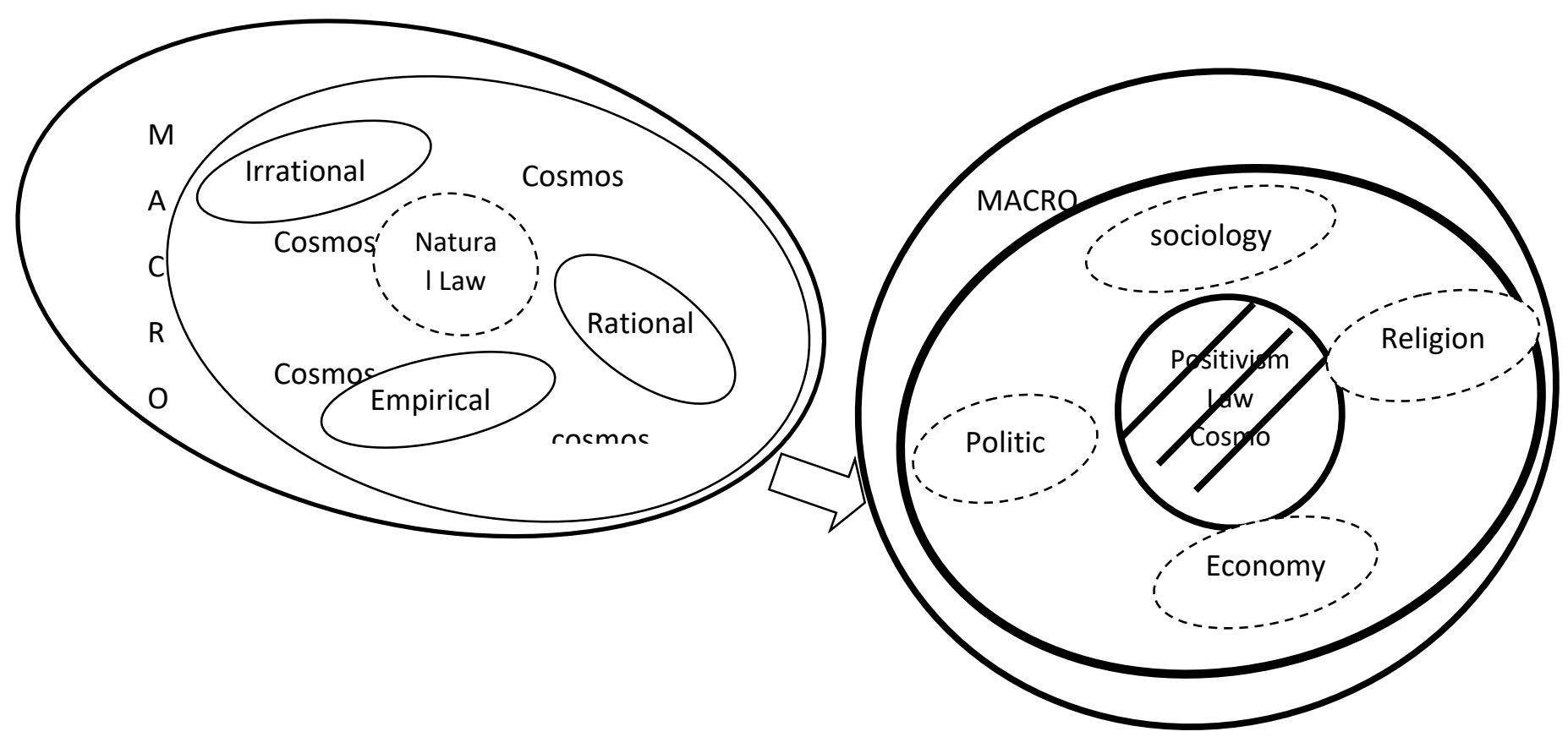

Figure 4. Positivism in a broader scope

The dimension of positivistic gradually has paved the thinking path backward because the law is merely a safe and fair state, nothing more.

\section{B. Dialectics of Post-Positivistic Law}

\section{Non-systematic law}

Non-Systematic Law was born unconsciously and is a flowchart of jurisprudence as a result of the saturation of the positivistic law paradigm which is influenced by the dualism of reality that is built by Cartesian-Newtonian thinking which focuses on naturalism and anthropocentrism. Dualism generally includes the real and fundamental separation between consciousness and material, between mind and body, between the cogitans (soul) and extensa (object), and between values and facts. ${ }^{26}$ Furthermore, the dualism has created a separation between morals and law, between law of form and material, and even the norm perspective of sollen (must) and sein (reality), the concept of values contained in norms is based on right and wrong. ${ }^{27}$ 


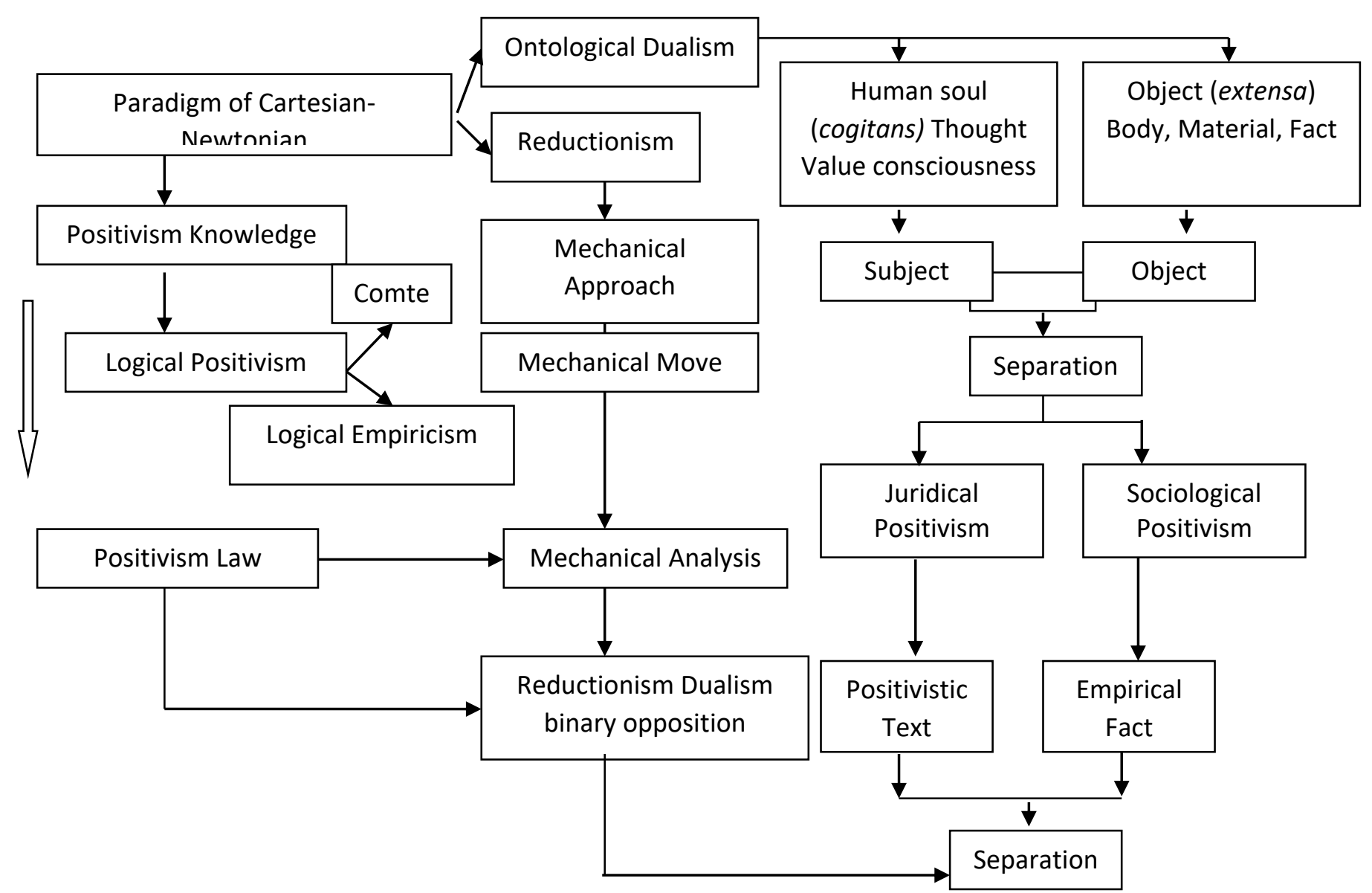

Figure 5.

The Influence of Dualism and Reductionism of the Cartesian-Newtonian Paradigm on

Positivistic Law

Non-systematic law provides a neat line of thinking outside positivistic, whether ontology, epistemology or axiology, which can explain the reality of reasoning beyond positivism with a variety of leaps of thought. The thinking flow of conflicts experienced by positivistic law occurs to build gradation relations in subject-object issues, so there is no dominance of subjectivity in understanding the law, non-systematic law has described understanding law in chaotic contexts, there is a transgression step in jurisprudence, so it allows intuition by following the Spiritual Quotient model of Danah Zohar and Ian Marshal, non-systematic jurisprudence takes the view of not accepting knowledge, reality and 
interpreting the law thoughtlessly based on the ground of study on chaotic theoretical frameworks in asymmetric laws or laws proposed by Charles Sampford and Jecques Derrida, non-systematic science of law explains the existence of Pancasila foundation as an open interpretation space in matters of justice which previously can only be enforced on a formal level. ${ }^{29}$ Thus, the implications of non-systematic and positivistic law differences are shown as follows:

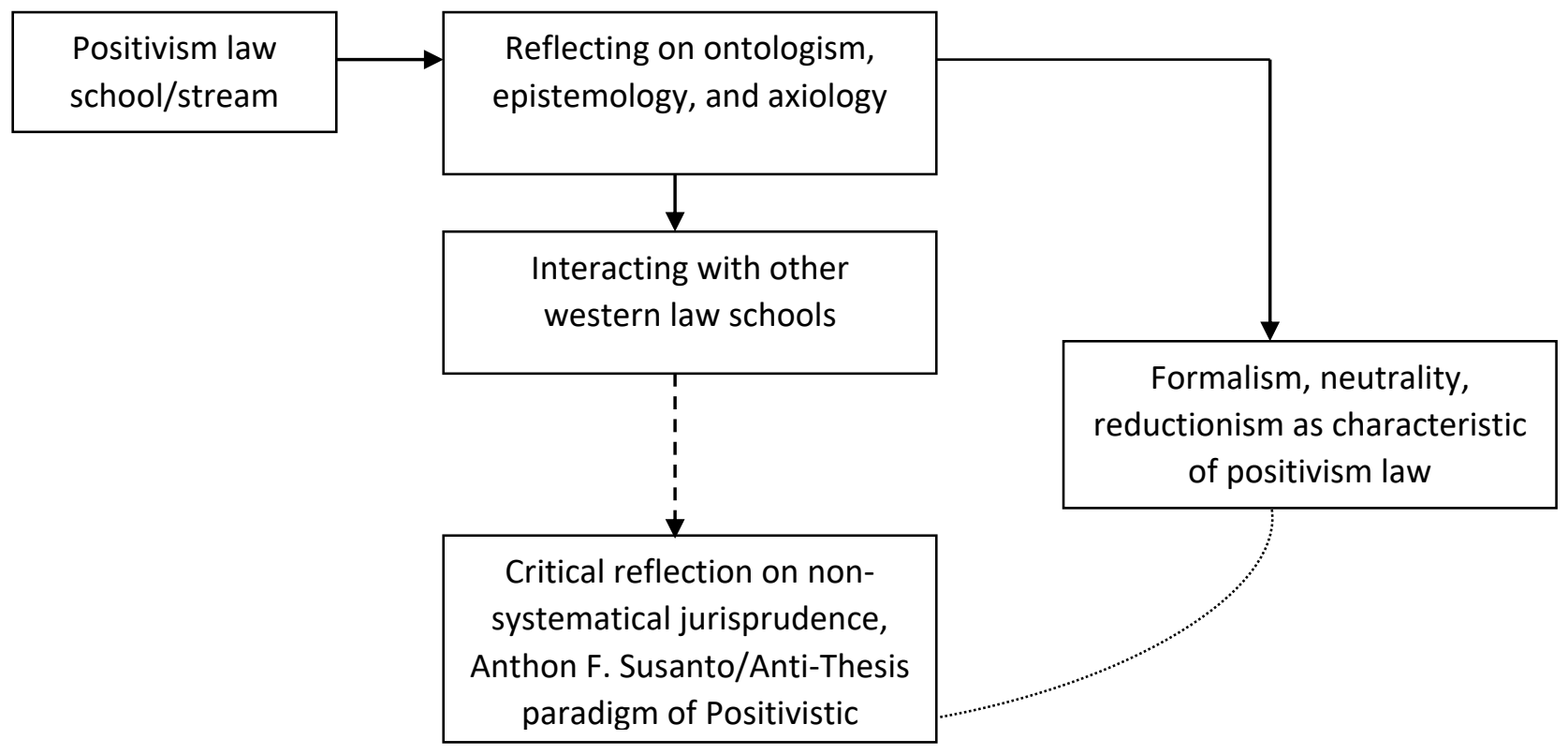

Figure 6. Ontology aspect of Non-systematic law ${ }^{30}$

Ontologism aspect, repositioning subject and object in the perspective of CartesianNewtonian dualism, epistemological aspect provides a more open, dynamic and accommodating design of legal analysis in diversity, non-systematic axiological aspect of legal certainty is ruled out and open more to melee justice because it results from uncertainty. ${ }^{31}$

\begin{tabular}{|l|l|l|}
\hline \multirow{2}{*}{ Epistemology } & Positivism law & Non-systematic Law \\
\cline { 2 - 3 } & $\begin{array}{l}\text { The distance between } \\
\text { researchers and the object } \\
\text { of the research }\end{array}$ & Relation and gradation \\
\hline
\end{tabular}




\begin{tabular}{|l|l|l|}
\hline \multirow{2}{*}{} & $\begin{array}{l}\text { Dogmatic-rationality- } \\
\text { empiricism-quantitative }\end{array}$ & $\begin{array}{l}\text { Consilience } \\
\text { approaches }\end{array}$ \\
\cline { 2 - 3 } & Reductionism & Pluralistic-holistic \\
\cline { 2 - 3 } & Syllogism on the logic & Deconstruction, chaos \\
\hline
\end{tabular}

Table 2. Design of Legal Analysis in Epistemological Aspects ${ }^{32}$

The axiological aspect of non-systematic law emphasizes the gradation relation in Pancasila which was reconstructed by Anthon, to the ground that basically non-systematic law is a study to develop Indonesian law that cannot be separated from Pancasila.

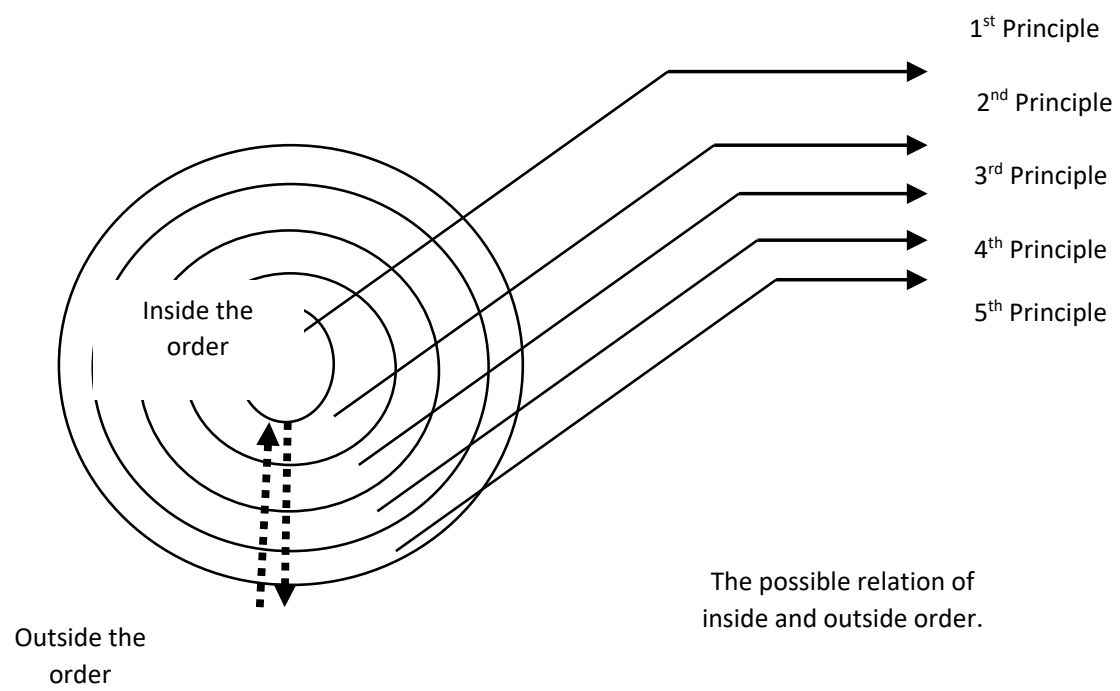

Figure 7. Axiological aspects of non-systematic law ${ }^{33}$

Legal norms will continue to move chaotically in accordance with the interpretation process of that occurs, this is a process of reading norms that allows the presence of other realities. ${ }^{34}$ However, in the development of non-systematic law thinking, there is still a reality that cannot be explained, although with the concept of consilience approach, however, natural phenomenon of non-systematic reality at a certain level meets with deficiencies, this is conveyed by the thinkers themselves, thus raising criticism of the non-systematic law as a concept in the complete development of the philosophy of law. The criticism is proposed based on paradigm ontology, epistemology, and axiology that emphasizes prophetic studies. These criticisms are: 


\begin{tabular}{|c|c|c|}
\hline Aspect & Non-Systematic & Prophetic \\
\hline Ontology & $\begin{array}{l}\text { Relation } \\
\text { (eliminate Cartesia and } \\
\text { Newtonian) }\end{array}$ & $\begin{array}{l}\text { Integralism; humans as the } \\
\text { shallowest source and God } \\
\text { as universal primacy }\end{array}$ \\
\hline Epistemology & $\begin{array}{l}\text { 1. Ratio, 2. Emotion, } 3 . \\
\text { Intuition, 4. Chaos. } 5 . \\
\text { Chaos in norm and text }\end{array}$ & $\begin{array}{l}\text { 1. The source of } \\
\text { knowledge is prophecy, } \\
\text { sunnah and hadith } 2 \text {. The } \\
\text { source of knowledge is } \\
\text { relative; holy books of } \\
\text { knowledge generally, } \\
\text { Nature, reality, social and } \\
\text { law }\end{array}$ \\
\hline Axiology & $\begin{array}{l}\text { Deconstruction of } \\
\text { Pancasila (relativization), } \\
\text { the fall of state authority as } \\
\text { the creator of law }\end{array}$ & $\begin{array}{l}\text { The radicalism of } \\
\text { Pancasila as the state's } \\
\text { ideology. Reconsistency of } \\
\text { the state as the holder of } \\
\text { trust forming law to side } \\
\text { oppressed people. }\end{array}$ \\
\hline
\end{tabular}

Table 3. The paradigm of ontology, epistemology, and axiology in prophetic studies ${ }^{35}$

\section{Dialectics of Prophetic Legal Thought Synthesis}

The need to retrieve the central view of existence is increasingly urgent for mankind, because the value of the illusions they create surrounding themselves, to forget the divine transcendent dimension of their lost lives. ${ }^{36}$ The transcendental paradigm can be seen in a wider range of religious, ethical, and moral values, and the problem of these values can be conversed with the development problem of scientific, social, cultural, economic, and legal, ${ }^{37}$ by carrying out transcendental values humans can explore the ultimate truth, which truth is not merely at the level of objective reality but at subjective and inter-subjective realities, humans need such intelligence, referring to Danah Zohar and Ian Marshal in combining objective, subjective and inter-subjective realities in unity to present a near-perfect science, because 
human has the voice of conscience which is called by Agustian Ary Ginanjar as God Spot, which is mudghoh who whispers, conveys and speaks the truth. ${ }^{38}$

Divine beauty in poetry can provide enormous benefits to solve the problems of modern humans ${ }^{39}$ and to realize lives that are connected to religious teachings, the integration of religion with science. The metaphorical and mystical teachings of Islam are the most capable of providing urgent answers in this circumstance. This flow is offered by Kuntowijoyo with his prophetic sciences. The behavior to understand the flow of prophetic thinking is to understand the Divine reality in the Quran as the reality of the Quran to understand it as a flow chart of thinking. Prophetic construction was built on the foundation of the Quran, so we can find not only factual but also the dimensions of the factual reality of the Qur'an. ${ }^{40}$ As a science, Prophetic Paradigm was developed by Universitas Muhammadiyah Surakarta with the philosophies of humanization, literacy, and transcendence. ${ }^{41}$ As a manifestation of the prophetic law implementation in the future, it produces thoughts that are based on Divine relations based on the Quran and Sunnah. The development of this relationship is neither simple nor unilateral, but dual and bilateral, in the sense of reciprocal relations. ${ }^{42}$ Poetic relations provide answers to the relationship between text and context. The Quran is not only a revelation but also dimensioned as factual science.

Kuntowijoyo built this relationship into three categories; theology, humanity and natural science. $^{43}$

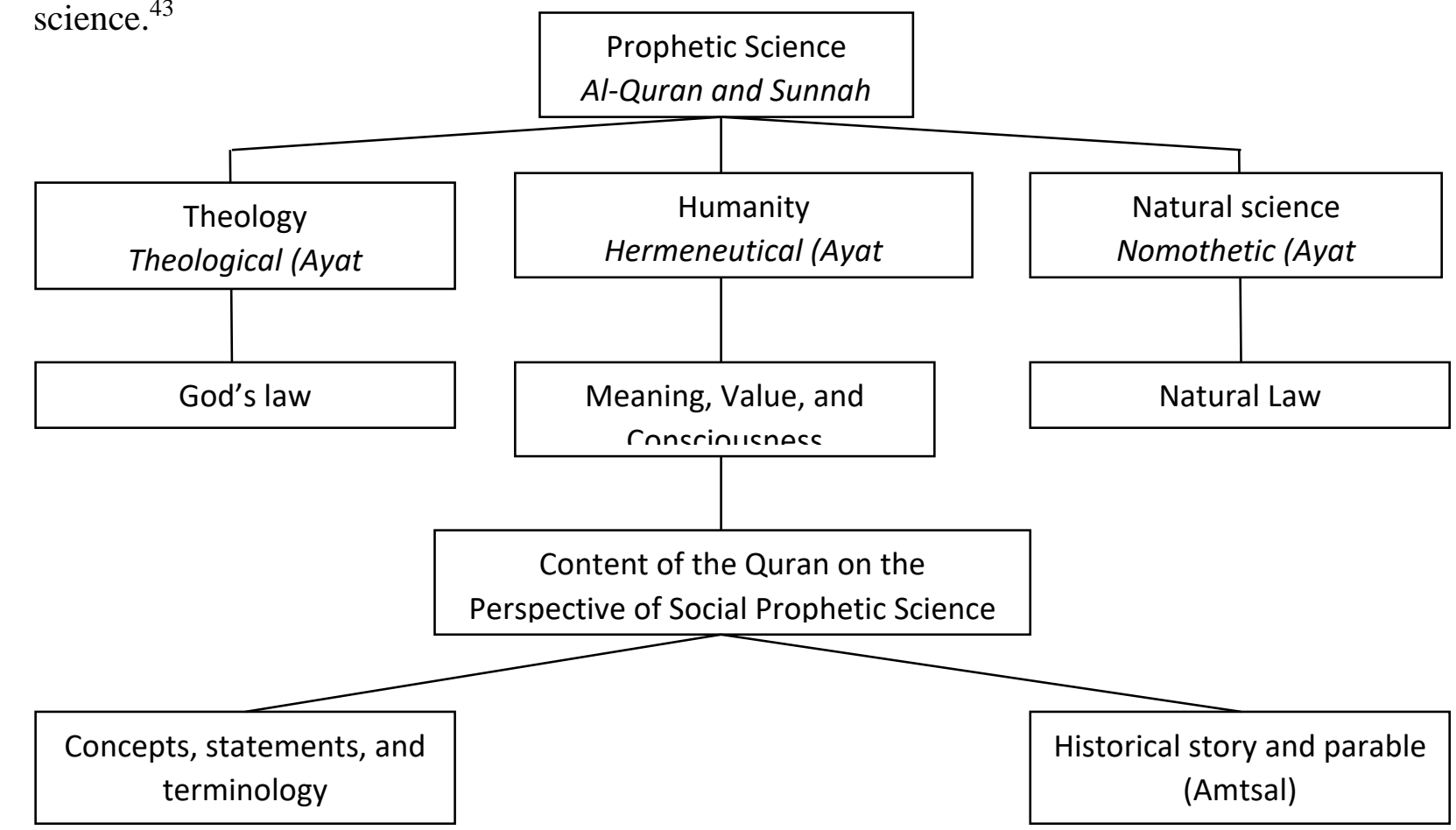


Figure 5. Prophetic Construction According to Kuntowijoyo ${ }^{44}$

Based on the demonstration of the concept above, it is obvious that the prophetic concept is sourced from rational factual of Divine. From the dimension of our view is originally the basis of the revelation outlined in the Qur'an and Sunnah. The Qur'an emphasizes that the most dominant principle is the relation of the text and the context with the goal meaning of being maslahat/benefit. To determine the benefits or not, the benchmark does not lie on human taste or lust, but the word syara'. ${ }^{45}$ Thus, the picture of the prophetic law can be seen in figure 6. The Supreme Reality, the God, is the One and the Zhahir (reality). Religious humans perceive God as inner. Others who completely forget their spiritual realm only view at Zhahir. Due to the unknowingly conscious of the Center, one does not realize that Zhahir is a manifestation of the Center or God. Therefore, the fragments of knowledge one acquires cannot cover the whole edge of the circle, moreover the center of existence. ${ }^{46}$

\section{CONCLUSION}

The existing legal paradigm is a scientific reality within a philosophical framework, its existence as a basic framework of thinking regarding the law. The phenomena of various legal paradigms that develop simultaneously complement each other as a synthesis of the development of legal science and as an answer to various problems of legal philosophy. Positivistic, Non-systematic and Prophetic paradigms are the path to near-perfect truth. The Prophetic paradigm developed in the framework of micro and macro realities are considered capable of providing answers to the reality of various criticisms that have existed so far, although this paradigm has only become an embryo, but the paradigm developed by UMS thinkers, such as Khudzaifah Dimyanti and Absori, is not only limited to embryos. However, it can be a new answer, prophetic paradigm marries micro, macro and transcendent realities based on God's verses on the Qur'an and Sunnah which are divided into 3 categories of Theology, Humanity and Natural Sciences. 


\section{REFERENCES}

Absori et al. 2018. Hukum Profetik Kritik Terhadap Paradigma Hukum Non-Sistematik. Genta Publishing, Yogyakarta.

---------, 2015. Epistimologi Hukum Transedental dan Implementasinya Dalam

Pengembangan Program Doktor Ilmu Hukum. Prosiding Seminar Nasional April 2015

di Universitas Muhammadiyah Surakarta.

-. 2018. Kritik Terhadap Paradigma hukum Non Sistematik. Materi Kuliah Filsafat Hukum Program Pascasarja UMS.

Bakir, Herman. 2005. Kastil Teori Hukum, PT Indeks kelompok Gramedia, Jakarta.

Bakhtiar, Amsal. 1997. Filsafat Agama, Logos, Jakarta.

Diane Collinson, 2001. Lima Puluh Filosof Dunia yang Menggerakkan, Jakarta: PT. Raja Grafindo Persada.

Dwi Putro, Widodo. 2011. Kritik Terhadap Paradigma Posivisme Hukum. Genta Publishing; Yogyakarta.

FX. Adji Samekto. Menggugat Relasi Filsafat Positivisme Dengan Ajaran Hukum Doktrinal, Jurnal Dinamika Hukum. Vol. 12. No. 1. 1 Januari 2012.

Ghofur Anshori, Abdul. 2006. Filsafat Hukum, Gajah Mada University Press, Yogyakarta.

Hossein Nasr, Sayyed. 1983. Islam dan Nestapa Manusia Modern. Pustaka. Bandung.

Mr. Soetikno.2003.Filsafat Hukum Bagian 2. Pradnya Paramita. Jakarta.

Mr. Soetikno.2003.Filsafat Hukum Bagian 1. Pradnya Paramita. Jakarta.

M, Hajar. Dialektika antara Aliran Hukum Alam dan Hukum Positif dan Relevansi dengan Hukum Islam. Jurnal Hukum IUS QUIA IUSTUM NO. 4 VOL. 20 OKTOBER 2013: $563-579$

Munif Suratmaputra, Ahmad.2002. Filsafat Hukum Islam Al-Ghazali, Masalah Musalah dan relevansinya dengan pemharuan hukum Islam. Pustaka Firdaus. Jakarta.

Prasetyo, Teguh et all. 2006. Ilmu Hukum dan Filsafat Hukum Studi Pemikiran Ahli Hukum Sepanjang Zaman. Pustaka Pelajar, Yogyakarta.

Suharto. Bekti Menyoal Sudut Pandang: Kritik Terhadap Epistemologi Positivisme Hukum. Prosiding seminar nasional. 
Sumaryono, E. 2002. Etika Hukum Relevansi Teori Hukum Kodrat Thomas Aquinas. Kanisius, Yogyakarta.

Susanto, Anthon F.. 2010. Ilmu Hukum Non Sistematik "Fondasi Filsafat Pengembangan Ilmu Hukum Indonesia" Genta Publishing; Yogyakarta.

2010. Dekonstruksi Hukum "Eksplorasi Tesk dan Model Pembacaan" Genta Publishing; Yogyakarta.

Syukri Albani Nasution, Muhammad, et all. 2015. Hukum Dalam Pendekatan Filsafat. Kecana. Jakarta. 